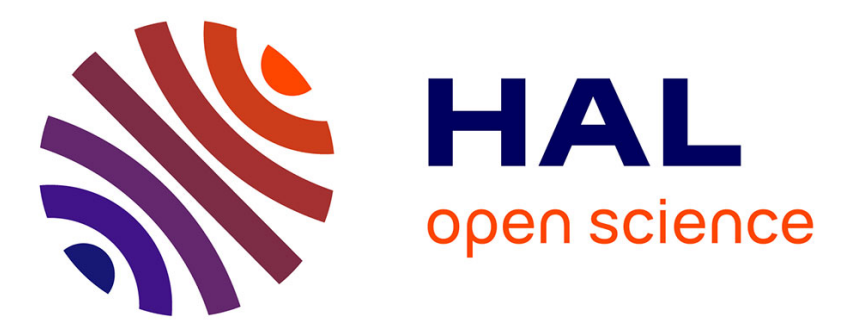

\title{
AIDS AND HUMAN RIGHTS: A SOCIETAL CHOICE
}

Daniel Borrillo

\section{To cite this version:}

Daniel Borrillo. AIDS AND HUMAN RIGHTS: A SOCIETAL CHOICE: Juridical Reflections on the Spread of H.I.V.. René Von Schomberg. Science, Politics and Morality: Scientific Uncertainly an Decision Making, Kluwer Academic Publishers, 1993, 0-7923-1997-4. hal-01238295

\section{HAL Id: hal-01238295 https://hal.science/hal-01238295}

Submitted on 4 Dec 2015

HAL is a multi-disciplinary open access archive for the deposit and dissemination of scientific research documents, whether they are published or not. The documents may come from teaching and research institutions in France or abroad, or from public or private research centers.
L'archive ouverte pluridisciplinaire HAL, est destinée au dépôt et à la diffusion de documents scientifiques de niveau recherche, publiés ou non, émanant des établissements d'enseignement et de recherche français ou étrangers, des laboratoires publics ou privés. 


\section{AIDS AND HUMAN RIGHTS: A SOCIETAL CHOLCE Juridical reflections on the spread of II.I.V.}

Daniel BORRILLO

GERSULP (Groupe d'Etude et de Recherche de la Science de l'Université Louis Pasteur) Strasbourg

\subsection{Introduction}

It was not so long ago that the industrialized societies thought that they had conquered the plagues of infectious diseases. Mortality rates in France showed that the principal causes of death had become: heart disease, cancer, suicide and traffic accidents'.

In 1981, however, United States federal authorities noted a considerable increase in the distribution of a medicine named pentamidine isethionate, used in the treatment of a type of pneumonia known as pneumocystis carinii, which affects sick patients whose immune system had been deteriorated by cancer. The illness was so unusual to the extent that its treatment was considered purely experimental. Between 1967 and 1979 there had been only two prescriptions written for this previously mentioned medicine.

The first five cases of AIDS discovered in 1981 had several points in common. They all involved young homosexuals whose immune systems, up till their diagnosis, had been functioning normally. At the same time, the appearance of several cases of a known but quite rare cancer named Kaposi's sarcoma and pneumonia was discovered in the same population cited above. Other equally peculiar illnesses were progressively detected which had the same common denominator, that being the same impairing effect on the immune system.

The relationship was quickly established and in 1982 was recognized by the clinical community. The newly identified syndrome was first called G.R.I.D. - Gay Related Immune Deficiency (whose terminology was quickly considered too limited because it makes a relational link between an immune deficiency and male homosexuality), and later called A.I.D.S. Acquired Immune Deficiency Syndrome - which was considered more appropriate. AIDS is caused by a chronic immune deficit whose etiological agent is a retrovirus ${ }^{2}$ which represses the most serious infection of the 
virus. The illness was detected in the same year (1982) in a group of several Haitian and hemophiliacs. This confirmed the hypothesis that the transmission of the virus was through both blood and sexual activities. In 1990, the World Health Organization (W.H.O.) estimated that there was approximately 283,000 full blown cases of AIDS and that more than $8,000,000$ individuals who are carriers ofan asymptomatic form of the virus. These individuals are known as 'seropositives.' Faced with this peculiar illness, the international press' first reaction was to establish a direct relationship between the disease and the "gay community." In the eyes of the general public, the illness was presented as a sort of "Homosexual Chernobyl. ${ }^{3}$

The history of epidemics well illustrate how man has reacted in the face of a plague from an unknown origin. In trying to find their "evil" origins in certain social groups, as in the case of the "Black Death" plague of the 8th Century which decimated Europe, the Islamic nations played the role of 'onlookers', absolved from the drama. Their first reaction was to identify the "evil" with the Christian communities who generally appeared the most affected (probably because they stayed closely together in tight circles). To think that a virus could choose its victim according to his professed religion would seem absurd today!

In the same fashion during the Second Plague (1348-1352) which in no time whatsoever wiped out a third of Europe's population, Christianity considered it a punishment from God, whose divine anger found the responsible parties. The Catholic Church found its scapegoat in all who didn't profess to the Christian faith. It wouldn't be necessary to recall the expulsions of the Jews and the Gypsies from major European cities during this period.

Man has always found himself needing to explain the catastrophes to which he is regularly subjected. For this matter, we are sometimes surprised by the reasoning used to analyze and to represent epidemics ${ }^{4}$. Apart from the previously cited examples, we are able to furnish an interminable list of interpretations given to illnesses. Let's take several examples: Various ancient Mesopotamian texts provide us with explanations of illness brought on by the anger, and even caprices of the gods. Freckles appearing on a baby's skin as a consequence of an infectious disease were interpreted as scratch marks of the devil Iamashtu ${ }^{5}$. Later, the concept of "moral conscience" was born. The gods no longer pursued innocents, but 
punished the guilty (those who violated sacred places, who did not respect agricultural rites or who committed incest, notably).

Though the Occident had undergone a process of secularization over the years, the causal relationship of disease-responsible/disease-punishment had not altogether disappeared from modern medicine, e.g. the victim of lung cancer is punished for having smoked too much, hence those with AIDS are being punished for their loose sexuality or promiscuity ${ }^{6}$.

Over the years, the relationship of AIDS-homosexuality fulfilled a reassuring function for the rest of the "heterosexual society." A "normal" sex life permitted people to feel apart from the scourge of AIDS. It wasn't until 1986 that AIDS became an illness which came to concern everybody by the simple fact that the possibility of a heterosexual transmission was proven.

According to M. Pollak ${ }^{7}$, AIDS, having its origin in the closest held taboos of Occidental society - blood, sperm, sex, homosexuality and death, has created a quasi-experimental situation by putting to a test the meanings of tolerance and freedom. It thereby challenges the capacity of a democracy to respond to unforseen threats to the very pillars of its society.

\subsection{Epidemic Management by the rule of law}

A democratic society characterizes itself principally by its government's organization, structure and its responsibility to its citizenry and the individual. Constitutional law is characterized by the respect of what we call the rule of law ${ }^{8}$, formed around two major principles: the principle of legality which is a complex ensemble of formalities and procedures whose goal is the distribution and limitations of powers which protect personal freedoms. The second is the democratic principle which, because the constitutional state must be democratic, as it grants the population access to power.

The history of infectious disease management and epidemics is characterized by strict measures of control and by limiting personal liberties in the name of the general health risks to the society at large ${ }^{9}$. Beyond the generally accepted reasons for reducing the possibility of a contagion, the management of an epidemic responds to the structural exigencies which 
embrace a larger vision...that of the political agenda behind the government's epidemic management.

We find two principal tendencies in the following public health propositions. The first tendency is to take into account the premise of the constitutional state and the sick citizen, and the other of a strong policy of interventionist management based on a type of integrationist ideology which justifies a type of defense of the "seronegative society."

Freedom is in danger when the State assumes the power to decide in the place of the individual, for liberty by definition limits the State to that which is necessary to protect the rights of others. This jumbled ensemble of rights which explain the notion of public order is where we find the category of "public health." The existence of these two restrictions inevitably opens to unending debate the sensible limitations which are capable of bearing on our personal freedoms. Professor Patrick Wachsmann noted that the European Convention on human rights carries a precious clarity when it specifies that the restrictions of certain liberties which are not proclaimed legitimate are conditionally subjected to being "necessary in a democratic society for the safeguarding of certain values which are the rights of others and the protection of public health. ${ }^{10 "}$

Which brings us to think about two major and fundamental principles in the management of the epidemic and the rule of law: the refusal to adopt emergency legislation and the prohibition of the State to interfere in the personal decisions of its citizens. In order to insure the maintenance of public order, and asserting the existence of a crisis which puts the entire society in danger, the State is sometimes tempted to create and apply emergency legislation. Legislation which involves an extension of executive branch powers, as was the case, for example, in the September 9 , 1986 French government's special directive against terrorism.

Up to now, the adoption of emergency legislation concerning AIDS has been rejected, and it is hoped that this decision should be firmly supported. Because of its means of transmission, AIDS differs from other epidemics and does not, therefore, threaten the population as a whole. Contamination is principally produced by contact with blood or sperm and can be avoided by using sterilized syringes and condoms. In the most commonly known high risk situations, e.g. blood transfusions, organ donorship or artificial insemination, an AIDS-blood test is mandatory". A call to individual responsibility in prevention must be stressed. In France, the government, 
working in partnership with certain associations has proven itself very efficient in this effort.

\subsection{The role of the physician under the rule of law}

Beyond the ethical rules which doctors have come to respect as a function of their professional codes, constitutional law has established a certain number of both general and mandatory measures. Just as a medical secret comes to be represented as part of medical ethics, it is necessary to underline that it is also legally bound by Article 378 of the French Penal Code $^{12}$ which established sanctions against those who divulged confidential information gathered under the doctor-patient relationship ${ }^{13}$. There can obviously be no medical secrets between the doctor and the patient who has the right to his medical data. In this regard, the French National Consultative Committee on Ethics declared the necessity of informing patients, under acceptable circumstances, of their medical condition taking into account the psychological state of each patient ${ }^{14}$. Under French law, Decree $\mathrm{N}^{\circ}$ 86-770 makes it mandatory to report each case of AIDS (though not the seropositives) and it must be done anonymously, to the DASS (Direction des Actions Sanitaire et Sociale). This mandatory reporting constitutes the sole exception to the principle of medical secrecy.

The problem becomes more complex at the moment when this sensitive medical information enters medical information systems. La Commission Nationale de l'informatique et des libertés (CNIL), concerned by the problems posed by the development of data access and the individual's right to privacy, adopted strict measures regarding the treatment of AIDS research and patient files ${ }^{15}$. Among the problems cited was the possible misuse of medical data, whether exploited for political or financial ends, which could put fundamental freedoms in jeopardy ${ }^{16}$.

If the patient's name is required to be recorded ${ }^{17}$ in all epidemiological cases, the AIDS patient's name must be rendered anonymous prior to his case information being placed into a medical data bank ${ }^{18}$. Anonymity is at the core of the reconciliation of the patient's right to privacy, and the protection of research data. Every part of the patient's file must be declared to the CNIL which examines the adequacy and relevance of the records with respect to the defined limits set forth by the declarant. All recorded information must rely on the patient's consent, who, in any case, 
is authorized to have access to his file but who can also reconsider his decision ${ }^{19}$.

But this isn't the only level of the violation of legal norms put into question by the rule of law. In other widespread, though less serious situations, we see a profile of a distinct abuse of power on the part of the doctor, notably when he assumes a moralizing role with the patient. An inevitable dependency relationship becomes established between the ill patient and the doctor. This relationship must be accompanied by an ethical responsibility which constantly stresses that the ill patient (or the seropositive) is a private citizen - and that the doctor is in no way authorized to exploit his position and act as a moral figure in the patient's private life.

\subsection{Words and Deeds in official epidemic management}

Using metaphors borrowed from medical vocabulary, the ideology of hygiene has claimed to explain the functioning (or disfunctioning) of society. Such was the case when articulating the 19 th and 20th Century character of Italian anthropological studies of criminality ${ }^{20}$ which started the acclimation of certain terminology into continental European themes. These themes went on to abundantly serve totalitarian regimes who protected the "healthy body of society" from "foreign bodies" and the "virus" which came from the "infected": born criminals, congenital idiots, the insane and sexual deviants..." ${ }^{21 "}$ In the authoritarian view, democracy isn't capable of maintaining the "healthy" social body and at the same time eliminating infectious elements from $\mathrm{it}^{22}$. Democracy is put into question, according to them, because of its laxity and dangerous permissiveness vis à vis its people and it is that which is at the origin of decadence. Too much freedom, too much tolerance towards "fags", too much understanding for drug addicts, too much contact with strangers (especially Africans). Here we have several mythical explanations and imagery which has found its way into our common parlance, spawned by certain politicians and certain members of the scientific community ${ }^{23}$.

Metaphorical language ${ }^{24}$ doesn't take the facts into account, it doesn't leave itself to the realization of its own prophesies. Let us remind ourselves' of the altogether unjustifiable excesses, from the scientific point of view, which we've witnessed in recent times. The closing of establish- 
ments where AIDS was spread (Decision of the Bavarian Ministry of the Interior, February 25, 1987), the expulsion of all foreigners who constitute an AIDS -related risk (ditto, May 19, 1987); the authorization to quarantine all HIV positive patients in the State of Texas (USA), the obligatory hunting down and systematic imprisonment of seropositive individuals in Cuba; the prohibition to enter American territory for seropositive and AIDS-infected individuals at the time of the most recent international AIDS conference in San Francisco; the power given to Rumanian doctors to mandatorily hospitalize infected individuals. These examples, among many others ${ }^{25}$, are instead the result of the fruit of metaphors ${ }^{26}$ and discursive ensembles which have strongly conditioned health policies. For ages we've heard talk of divine plagues, of a combat against a virus, of excessive freedoms and the creation of a virus which serves the purposes of conservative and puritanical forces, etc.

It is time to break away from these stereotypes and metaphors and meet the obligation of creating the most realistic and reasoned management of the epidemic. According to Susan Sontag, the most honest attitude we could have towards the illness and the most honest way of being sick oneself is to weed out its metaphor and resist the contamination which accompanies $\mathrm{it}^{27}$.

\subsection{The epidemic in the state of European law}

The Council of Europe is particularly concerned with the struggle against the epidemic because, as underlined by Mme Massarelli ${ }^{28}$, the Council's director of heath services, what is in question poses a major challenge to public health policy itself. The Council's work is carried out within a general framework of recommendations by WHO, and its goal is that its findings would influence a harmonization of European legislation on the issue. Making human rights an imperative of public health is the fundamental preoccupation and primary axis on which all of the Counsel's recommendations are organized.

In order to limit the spread of AIDS, the Council proposes to win the confidence of HIV infected persons. Any measure of coercion or discrimination could provoke a negative reaction in the infected community, as well as in the general population. It is a given that the indispensable means in the management of an epidemic is information and prevention, but it is 
difficult to see how a collaboration between the State, the AIDS carriers and the seropositives would come about in this management. The only strategy considered acceptable by European juridical order, with respect for both efficiency and personal rights, was that of a prevention policy composed of information dissemination, education, voluntary testing, counseling and complete respect for confidentiality. A draft bill at the Counsel of Europe was quickly introduced.

In 1983, even before the virus was isolated, the Council presented its first report which recommended that transfusion services suggest a selfexclusion policy for would be donors belonging to risk groups ${ }^{29}$. The French National Assembly equally demanded that the private lives' of individuals should be respected and that information campaigns should not be directed towards any one social group ${ }^{30}$. In 1985, once the virus was discovered, the Committee of Ministers recommended mandatory AIDStesting of blood donors to track down the virus ${ }^{31}$. Other recommendations were proposed by the Counsel trying to systematically take into account the legal principles necessary in respecting individual rights at the benefit of public health ${ }^{32}$.

\subsection{Examples of loopholes in the rule of law}

Despite the international institution's efforts, a number of dubious legal situations continue to arise. Beyond the serious steps taken by public authorities in a considerable number of countries, the situation in Europe is far from being worked out, aside from the cited cases of Bavaria, Belgium or Ireland - certain practices of some French institutions make a call for reflection. As an example, we'll take the case of the right to insurance and labor laws ${ }^{33}$.

The French National Committee on AIDS recommended in its February 20, 1990 declaration that it was "forbidden for insurance companies to subordinate to conclusion an insurance policy based on the results of a blood test for the AIDS virus." It equally advised that it would "be vigilant that insurers did not introduce questions in their applications which made reference, in an explicit or indirect way, to the applicant's style of life or sexuality." Despite these recommendations, insurance companies maintain discriminatory practices to this day. 
The French insurers complain that they bear the cost of medical secrets in France, which hinders the creation and exploitation of samples, which lead to actuarial tables which aid them in better ascertaining their insurance risks ${ }^{34}$. Mr. Pierre-Denis Champvillard, the director general of Scor-Vie, a company specializing in reinsurance confirms: "If we decide to mutualize the 'AIDS risk', it would inevitably raise the premiums for clients who are not seropositive. They'll (non-seropositive clients) go elsewhere, to London, for instance."

A draft bill which would nullify the application of Article 416 of the French Penal $\mathrm{Code}^{35}$, the very code which protects applicant from being discriminated against by reason of physical condition or handicaps, has as its goal to allow insurers to limit their types of coverage to AIDS patients $^{36}$. The insurance lobby is claiming that not only should mandatory AIDS-testing take place for applicants, independent of a covered risk $^{37}$, but also for the establishment of insurance industry files on all seropositives. As Pierre Lascoumes points out, the insurance companies are in the process, in effect, of obtaining the authorization to accomplish that which they swore they would never do...of knowingly excluding seropositives from individual insurance policies. Let us call attention to the fact that such a measure has never taken place for any other illness, even those which result in more deaths than AIDS. There has never been, for example, a similar requirement for mandatory tumor testings for cancer.

The situation with labor laws has been no less dramatic. The French National Committee on Ethics in its December 16, 1988 decree (2.D.) established that "being seropositive would not be considered an obstacle in the exercise of professional activities, public or private, and did not entail, for example, a job disqualification," on this general principle the committee quickly added "It might appear in the future that the exercise of certain professions will be incompatible with being seropositive - this is for two reasons - on the grounds of the transmission risk of the illness to others, and on the grounds that the pathological consequences for others may arise, as well. These situations, in all likelihood, are exceptional and should be the subject of study and special decisions."

In the same sense, it was recently recalled that relative questions of health were part and parcel of the individual's private life and by consequence deserved protection. It is on this basis that a private company was ordered to pay out damages with interest to one of its employees for having approved of the posting of a memo relevant to the seropositive state 
of the employee ${ }^{38}$. The theory is clear and simple, less so than in practice. Such is the current state of labor laws, and in considering the instruments at the employer's disposal (they are not all as naive as in Burke France), the seropositive, and more so the carrier, finds himself in a very precarious situation in the workplace. The afflicted worker progressively passes through the asymptomatic state towards the first symptoms of the illness when he is finally obliged to take leave and find and commit himself to a medical care facility. If the absences are prolonged, the employer can legitimately lay the worker off. Furthermore, no provision of the French Labor Code permits an employee to ask to rearrange his working hours in order to enroll in a medical treatment program, when in Article L. 212-4-12 of the same Code legitimizes this kind of request "for the regular and controlled practice of sport." One can say, as Pierre Le Cohu commented, that "the more you have, the more you receive; we give time off to do sports, but when it comes to a sick employee, he takes care of himself...if he $\operatorname{can}^{39}$."

These examples show that, with respect to law and society, the problems posed by AIDS are far from being resolved. From all the discussions by "specialists" we get the impression that the real debate has never taken place, which is, so to speak, how the thousands of seropositives, who continue to have a normal, daily existence want to work, want to play an active role in society, want to love and to live the rest of their lives' in the best way possible.

\subsection{Conclusion}

In this century of unending medical progress, there is an illness which takes on epidemic proportions, shocks worldwide opinion and puts the foundations of public health policies into question. The stakes are high, for the reactions and from the conflict sometimes awakens irrational, exaggerated fears of the illness. Statistically speaking, AIDS is much less widespread that other illnesses or accidental death, but it seems to have appeared in our society as a form of punishment.

For centuries, man has associated crises with the loosening of morals: The historian Sallustre estimates that in the 1st Century BC that the decadence of the time was due to the loss of virtus (courage, power of the soul..). Zosime, in the 5th Century $\mathrm{AD}$ holds the Christian religion 
responsible for the crisis of submissiveness leading to the loss of the healing virtue. Or more recently, in 1860, Francon writes that "If the inhabitants of the Occident are idiots incapable of withstanding hardship, then it is because they're degenerate ${ }^{40}$."

The philosophy of human rights gives us the possibility to think otherwise. It is in this way that AIDS reflects one of the most profound problems of our civilization, and it depends on us to place the debate on this level. To what degree is homosexuality tolerated in our society? When are we going to have an international consensus on the epidemic? What leads so many young people to turn to drugs to escape reality? Why have we chosen to attack AIDS victims in the place of the fight against the virus itself?

And so we've seen how the AIDS epidemic has put democratic societies face to face with a decisive choice; one which reveals the durability of the full meanings of tolerance, of the respect for privacy and of solidarity which we claim so much to defend. The way we manage this epidemic will surely define the society we leave to our children. In choosing the imperative for the rule of law in resolving the AIDS question, we are choosing our own freedom.

\section{Notes}

1. In 1985, INSERM (Institut Nationale pour la Sante et la Recherche medicale) printed the following statistics:

-app. 10,000 deaths attributed to traffic accidents $(9,985)$

-app. 12,000 deaths attributed to suicide $(12,363)$

-app. 15,000 deaths attributed to alcoolisme $(15,269)$

-app. 29,000 deaths attributed to tabacco- related illness $(28,550)$

2. It wasn't until after 1978 that scientists were able conceptualize and detect, due to biotechnical advances, a pathogenetic human retrovirus (H.I.V.). This data reinforces the hypothesis that the virus had existed for a long time except in a weaker less identifiable state.

3. The first headlines from the French press made exclusive reference to the homosexual community. The well known French journalist Escoffier-Lambiotte, wrote an article entitled "Mistérieux cancer chez les homosexuals américains. "("A mysterious American homosexual cancer") which appeared in Le Monde de la Médecine of January 27, 1982. Other publications used at the time the same terminology, as 
in "Lépidemie du cancer gay", Libération of March 19, 1983 or "Les homosexuels punis par le cancer," Le Matin of January 2, 1982.

4. "The history of syphilis in this respect is exemplary: the brutal appearance of this new plague, in 1493, was a mystery. Despite several discussions on the possible ways of transmission by the "niasmisms" or by breathing it in, venereal contagiousness has been recognized as its principal mode of transmission. From this mystery and this certitude should be born the belief that a divinely created disease was created to punish sinners." Sid'aventure, Ed. Syllepse, Paris, 1989, p. 58.

5. Ruffié J. and Sournia J.C., Les épidémies dans l'histoire de l'homme, Flammarion, Paris, 1984.

6. Sontag, S., La maladie comme métaphore, Le Seuil, Paris, 1979.

7. M. Pollak, Les homosexuels et le sida: sociologie d'une épidémie, Métaillé, Paris, 1988.

8. The Rule of law is the rule which must impose itself on all citizens, rich or poor, the governors or the governed. It is also known as a constitutional state or a democratic republic.

9. "Faced with leprecy, exile and detainment were organized to separate lepers and non-lepers. The plague was accompanied by various sectors which kept urban populations in their city, in their towns, in their districts and in their houses. The inhabitants were summoned to their windows so as to count the living, the sick and the dead." Defert, D., "Epidemics and democracy", Actions et Recherches Sociales $N^{\circ} 3$, September 1988, P.33.

10. Wachsmann, Patrick, "AIDS or the management by fear by the State of law" in Sida et droits de l'Homme: l'épidémie dans un Etat de droit, text from a conference convened by Borrillo D. and Masseran A., Actes du Colloque, Gersulp, Strasbourg, 1990.

11. Memorandum of the French Direction Générale de la Santé October 20, 1985 and October 28, 1987.

12. Professional secrets are bound under this code such that "all persons endowed by either the state or professional codes, or by a temporary or permanent function to whom secrets are confided" (religious, notary, process servers, etc.).

13. It would be difficult in this paper to thoroughly examine the French judicial system and the question of medical secrecy. We can refer interested readers to the work done by $\mathrm{D}$. Thouvenin in Le secret médical et l'information du malade, Presses Universitaires de Lyon, 1982. 
14. Notice of the Comité Consultatif National d'Ethique for science, life and health for the problems posed by the fight against the spread of infection from HIV (Human Immune Deficiency), December 16, 1988.

15. See E. Heilmann, "Medical Information Systems and the protection of nominative data in respect to HIV," Actes - Les cahiers d'action juridique) $\mathrm{N}^{\circ} 71-72$, June 1990, P. 36.

16. In a press release of November 1989, L'association Aides denounced the creation of a seropositive file by various insurance companies

17. Deliberation of the CNIL of September 1988 (Assistance Publique de Paris) $9^{\circ}$ Report of Activity, 1989, pp. 344-345.

18. Deliberation of the CNIL of July 5, 1988 (Assistance Publique of Marseille) $9^{\circ}$ Report of Activity, 1989, pp. 338-340.

19. The French Law entitled "Information technology and personal freedoms," January $6,1978$.

20. Especially with Lambroso and Ferri, In France, this school is principally represented by Lacassagne and Gabriel Tarde.

21. See Patrick Tort, "On cases of pscyho-sociological and fascistic rhetoric in the discussion of health." Sid'aventure, op. cit. p. 29.

22. In France, Le Front National claims that human rights legislation impedes an efficient approach to fighting the AIDS epidemic.

23. To the extent that Dr. Bachelot publically declared that AIDS-infected persons are "veritable bacteriological bombs" necessitating the creations of "aidsatoriums" in which to confine "aiddicts" who risk contaminating the healthy majority of the population. Interview in Liberration, February 1987. Not to forget the declarations of MR. L. Pauwels in Le Figaro magazine of December 6, 1986: " A group of measures for the society for not having taken disappear: selection, the promotion of personal efforts and individual responsibility, national codes, the fight against drug use, etc. the heresies. This return to reality is a scandal for them. They are afraid of their lack of morals. Here is their revolutionary sentiment. What we have here in our youth is a mental AIDS. They've lost their natural immunity; every terrible virus is attacking them."

24. Aristotle wrote that metaphor consisted of giving something a name which belonged to something else. 
25. In Great Britain, there is a draft bill (Criminal Justice Bill, Article 25) which would re-criminalize homosexuality. In Belgium, foreign students from non-EEC member countries are required to present a certificate of non-seropositivity at the time of enrollment. In Ireland, seropositive inmates are placed in special cells and subjected to "solitary confinement." Despite the Counsel of Europe's recommendations, Ireland and Belgium have not accepted to implement any promotional campaign on condom usage.

26. According to Sontag, AIDS has a double genealogical metaphor. Insofar as a microprocess goes, it is described like cancer: it's an invasion. When we throw in the mode of transmission, we run into an even older metaphor, linked to syphilis: pollution. (It is contracted through blood, from sexual fluids of an infected person or by contaminated blood products). Le sida et ses métaphores, Ch. Bourgois, Paris, 1989, p. 24.

27. Sontag, S., op. cit. p. 9.

28. Botho-Massarelli, Vera, "Ethical repercussions of AIDS in the framework of health and social policies," Sida et droits de l'homme: l'épidémie dans un Etat de droit, op. cit., p. 19.

29. Recommendation $\mathrm{N}^{\circ} 8$ on transmission prevention possibilities of AIDS acquired by contaminated blood donation or from blood products.

30. Resolution 812 (83) relative to AIDS

31. Recommendation 12 (85) on AIDS-testing for the presence of the signs of AIDS in blood donors.

32. Recommendation $12(85)$ in relation to a common European health policy against the spread of AIDS. Recommendation 1080 (88) of the Parliamentary Assembly. 8 th Conference of the national prison administrators. Recommendation (89) on the ethical implications within the health and social policies. Recommendation 1116 (89) of the Parliamentary Assembly concerning AIDS and human rights.

33. In other disturbing situations taken from some non-democratic positions can be found in common law, criminal law, penal law, etc. Interested readers will find more thorough explanations in $N^{\circ} 71$ of Actes "AIDS and the law," June 1990. From the records of a colloquium held at GERSULP, Sida et droit: la régulation. juridique d'une épidémie, Arles, Ed. Actes Sud, to be published.

34. Jean-François Rouge, "The Economics of AIDS," L'expansion, Jan. 24 / Feb. 6, 1991, p. 54.

35. Draft bill $N^{\circ} 1182(1990)$. 
36. See Lascoumes, Pierre, "When Insurance companies hunt bad risks. Seropositivity, an overestimated risk," Actes, op. cit., p. 72.

37. For seropositives having today, on average, eight more years of normal life before becoming full blown, the main problem isn't life insurance, but that of insurance linked to professional loans or supplementary insurance. The approbation of this draft bill involves an inadmissable discrimination.

38. The "Burke France" affair, Paris Grand Jury decision of June 7, 1989, cited by Françoise Degott-Keiffer, "New illnesses and the right to work, the case of HIV infection" in Sida et droit de l'homme: l'épidémie dans un Etat de droil, op. cit. p. 138.

39. "Employment, labor laws and AIDS," Acies, op. cit., p. 45.

40. These examples are analysed by Pascal Hintermeyer, "The AIDS idea" Action et recherches sociales, op. cit pp. 69-70. 